\title{
In Vivo Seeding and Cross-Seeding of Localized Amyloidosis
}

\section{A Molecular Link between Type 2 Diabetes and Alzheimer Disease}

\author{
Marie E. Oskarsson, ${ }^{*}$ Johan F. Paulsson, ${ }^{*}$ Sebastian W. Schultz, ${ }^{\dagger}$ Martin Ingelsson, ${ }^{\ddagger}$ Per Westermark, ${ }^{\S}$ and \\ Gunilla T. Westermark*
}

From the Departments of Medical Cell Biology, * Public Health/Geriatrics, ${ }^{\ddagger}$ and Immunology, Genetics and Pathology, ${ }^{\S}$ Uppsala University, Uppsala, Sweden; and the Centre for Cancer Biomedicine, ${ }^{\dagger}$ Oslo University Hospital, Oslo, Norway

\author{
Accepted for publication \\ November 6, 2014. \\ Address correspondence to \\ Gunilla T. Westermark, Ph.D., \\ Department of Medical Cell \\ Biology, Uppsala University, \\ SE-75123 Uppsala, Sweden. \\ E-mail: gunilla.westermark@ \\ mcb.uu.se.
}

\begin{abstract}
Several proteins have been identified as amyloid forming in humans, and independent of protein origin, the fibrils are morphologically similar. Therefore, there is a potential for structures with amyloid seeding ability to induce both homologous and heterologous fibril growth; thus, molecular interaction can constitute a link between different amyloid forms. Intravenous injection with preformed fibrils from islet amyloid polypeptide (IAPP), proIAPP, or amyloid-beta $(A \beta)$ into human IAPP transgenic mice triggered IAPP amyloid formation in pancreas in 5 of 7 mice in each group, demonstrating that IAPP amyloid could be enhanced through homologous and heterologous seeding with higher efficiency for the former mechanism. Proximity ligation assay was used for colocalization studies of IAPP and A $\beta$ in islet amyloid in type 2 diabetic patients and $A \beta$ deposits in brains of patients with Alzheimer disease. $A \beta$ reactivity was not detected in islet amyloid although islet $\beta$ cells express A $\beta P P$ and convertases necessary for $A \beta$ production. By contrast, IAPP and proIAPP were detected in cerebral and vascular A $\beta$ deposits, and presence of proximity ligation signal at both locations showed that the peptides were $<40 \mathrm{~nm}$ apart. It is not clear whether IAPP present in brain originates from pancreas or is locally produced. Heterologous seeding between IAPP and A $\beta$ shown here may represent a molecular link between type 2 diabetes and Alzheimer disease. (Am J Pathol 2015, 185: 834-846; http://dx.doi.org/ 10.1016/j.ajpath.2014.11.016)
\end{abstract}

Amyloid fibril formation is a self-propagating process that implicates a prion-like mechanism for amyloid growth and spreading of amyloid in tissues. Alzheimer disease (AD) and type 2 diabetes (T2D) are multifactorial diseases, but both have local amyloid depositions in their pathogenesis. In T2D, islet amyloid is made up by islet amyloid polypeptide (IAPP; amylin) ${ }^{1}$ (reviewed in Westermark et $\mathrm{al}^{2}$ ) that arises through posttranslational processing of its precursor, proIAPP. ${ }^{3}$ Accumulation of IAPP amyloid leads to $\beta$-cell death ${ }^{4,5}$ and development of diabetes. ${ }^{6-8}$ We have shown that incomplete enzymatic cleavage of proIAPP into IAPP triggers amyloid formation $^{9}$ and that the first intracellular amyloid in part consists of proIAPP. ${ }^{10}$ It is conceivable that amyloid that escapes elimination during cell debris clearance acts as seed and promotes extracellular amyloid growth. $\mathrm{AD}$ is the most common neurodegenerative disease, with a prevalence of $10 \%$ at age 70 years, ${ }^{11}$ and local deposits of $A \beta$ amyloid are present in cortex and vessels in the brain. ${ }^{12,13} \mathrm{~A} \beta$ peptide is generated by enzymatic cleavage of the precursor $\mathrm{A} \beta \mathrm{PP}^{14}$ (often referred to as APP), and accumulated data point to a partially intracellular route for $\mathrm{A} \beta$ plaque formation. ${ }^{15,16}$

Supported by grants from the Swedish Research Council (GTW5343), the Swedish Diabetes Association, and the Family Ernfors Fund.

M.E.O. and J.F.P. contributed equally to this work.

Disclosures: None declared. 
IAPP and A $\beta$ exhibit an overall $25 \%$ amino acid (aa) sequence identity, a property that increases in regions important for fibril assembly. ${ }^{17}$ Two regions of $A \beta$ (aa 11 to 21 and aa 23 to 37) with high binding affinity for IAPP, and two analogous regions on IAPP (aa 8 to 20 and aa 21 to 37) with corresponding affinity for $A \beta$ have been identified. ${ }^{18}$ These binding zones include residues that are important for self-assembly. Several clinical studies link together AD and T2D, and individuals with T2D have almost a twofold greater risk of developing $\mathrm{AD},{ }^{19-21}$ whereas other studies suggest an inverse relationship. ${ }^{22}$

We here show that intravenous injection of preformed fibrils of synthetic IAPP, proIAPP, or A $\beta$ in transgenic mice expressing human IAPP can act as a seed for IAPP amyloid in the islet of Langerhans. Morphological analysis with the highly sensitive and specific proximity ligation assay (PLA) of pancreases from T2D subjects and brain from $A D$ patients revealed colocalization of IAPP and $A \beta$ peptide in $A \beta$ cerebral plaques, whereas no $A \beta$ was detected in islet amyloid deposited in the endocrine pancreas.

\section{Material and Methods}

\section{Amyloid Fibrils}

Recombinant human proIAPP ${ }_{1-67}$ (hproIAPP), human IAPP $_{1-37}$ (hIAPP), and human des-31,32 proinsulin (CA) produced as described, ${ }^{23}$ and $A \beta_{1-42}$ (A $\beta$; Bachem, Bubendorf, Switzerland) (Figure 1A) were solubilized in dimethyl sulfoxide (DMSO) and diluted with distilled water to a final concentration of 100 $\mu \mathrm{mol} / \mathrm{L}$ peptide in $1 \% \mathrm{DMSO}$, and allowed to form fibrils overnight at room temperature.

\section{Animal Study}

Male mice (FVB; 4- to 6-week-old) expressing human IAPP behind the rat insulin-1 promotor, but deficient of mouse IAPP $\left(h I A P P^{+/+}{ }_{m I A P P}{ }^{-/-}\right),{ }^{24}$ and where islet amyloid starts to occur after 10 months on high-fat feeding were used for seeding experiments. Preformed fibrils of hproIAPP, hIAPP, $\mathrm{A} \beta$, and CA equivalent to $20 \mu \mathrm{g}$ of peptide in $100 \mu \mathrm{L}$ of 0.15 $\mathrm{mol} / \mathrm{L} \mathrm{NaCl}$ were sonicated 10 seconds (Vibra Cell; Sonic \& Materials, Danbury, CT) and injected in the tail vein of four groups of seven hIAPP transgenic mice. ${ }^{24} \mathrm{~A}$ fifth group of seven mice received an i.v. injection of $100 \mu \mathrm{L}$ of $0.15 \mathrm{~mol} / \mathrm{L}$ $\mathrm{NaCl}$. Mice were caged individually, maintained on a 12 hours light-dark cycle, and fed standard chow with free access to water and lard (Ellco Food, Gothenburg, Sweden) for 10 months. In addition, four groups of three mice each were injected with hproIAPP, hIAPP, A $\beta$, or CA fibrils and sacrificed 24 hours later. The study was approved by the animal ethics committee at Linköping University, Sweden.

At sacrifice, pancreas, spleen, liver, lung, heart, and kidney were collected, fixed in $10 \%$ neutral buffered formalin, and the presence of amyloid was investigated after Congo Red staining.

\section{Antibodies}

Antibodies and dilutions used in the present study are listed in Table 1.

\section{Slot Blot Analysis}

Reactivity patterns for antibodies produced against $A \beta 17$ to 24 (4G8), hIAPP 20 to 29 (A133), mIAPP 1 to 37 (A110), and hproIAPP 52 to 67 (A142) were scrutinized with slot blot analysis. A $\beta 1$ to 42 (Bachem), hIAPP (recombinant expressed), ${ }^{23}$ hproIAPP residues 52 to $67,{ }^{28}$ and human aCGRP 1 to 37 (haCGRP; Sigma-Aldrich, Stockholm, Sweden), were dissolved in DMSO, diluted in $50 \mathrm{mmol} / \mathrm{L}$ sodium carbonate buffer ( $\mathrm{pH} 9.6$ ), and applied (27 pmol) to nitrocellulose membranes (Hybond-ECL; GE Healthcare, Uppsala, Sweden). The membranes were boiled to expose epitopes and thus increase antibody binding in $4.3 \mathrm{mmol} / \mathrm{L}$ $\mathrm{Na}_{2} \mathrm{HPO}_{4}, 1.4 \mathrm{mmol} / \mathrm{L} \mathrm{KH}_{2} \mathrm{PO}_{4}, 2.7 \mathrm{mmol} / \mathrm{L} \mathrm{KCl}$, and 137 $\mathrm{mmol} / \mathrm{L} \mathrm{NaCl}$ (PBS), $\mathrm{pH} 7.4$, for 5 minutes in a microwave oven, blocked in a solution of $0.1 \%$ Tween- $20,50 \mathrm{mmol} / \mathrm{L}$ Tris-buffer with $150 \mathrm{mmol} / \mathrm{L} \mathrm{NaCl}(\mathrm{pH} 7.5)$ with $5 \%(\mathrm{w} / \mathrm{v})$ nonfat dry milk for 1 hour followed by incubation with A110, A114, A133, A142, or $4 \mathrm{G} 8$ overnight at $4^{\circ} \mathrm{C}$. Reactivity was visualized with horseradish peroxidaseconjugated secondary antibodies (Dako, Stockholm, Sweden) and chemiluminescence detection (Immobilon; Merck Millipore, Stockholm, Sweden).

\section{Tissue Extraction}

\section{Pancreas}

Ten sections $(20 \mu \mathrm{m}$ thick) from formalin-fixed, paraffinembedded pancreas from patients with T2D $(n=4)$ (Table 2) were collected in Eppendorf tubes and then deparaffinized and rehydrated. Tissue was incubated in $70 \%$ formic acid (FA) for 60 minutes followed by centrifugation at $16,000 \times g$ for 10 minutes. Supernatant was lyophilized and redissolved in DMSO.

\section{Brain}

Frozen temporal lobe brain samples (approximately $150 \mathrm{mg}$ ) from autopsy-confirmed $\mathrm{AD}$ patients $(n=4)$ and non-AD patients $(n=4)$ (Table 2) were recovered from the brain bank at Uppsala University. The tissues were homogenized with a mechanical homogenizer (Polytron PT-MR2100; Kinematica, Littau-Luzern, Switzerland) in $20 \mathrm{mmol} / \mathrm{L}$ Tris buffer, $137 \mathrm{mmol} / \mathrm{L} \mathrm{NaCl}$, and $2 \mathrm{mmol} / \mathrm{L}$ EDTA (pH 7.6) with protease inhibitors; $50 \mu \mathrm{g} / \mathrm{mL}$ phenylmethylsulfonyl fluoride, $1 \mathrm{mmol} / \mathrm{L}$ benzamidine, and $2 \mu \mathrm{g} / \mathrm{mL}$ aprotinin $(10 \mu \mathrm{L} / \mathrm{mg}$ brain tissue; Sigma-Aldrich) at $4^{\circ} \mathrm{C}$. The homogenate was centrifuged at $100,000 \times g$ for 1 hour at $4^{\circ} \mathrm{C}$ (TLA110; Beckman Coulter, Bromma, Sweden), and supernatant was collected (hereafter referred to as TB fraction). Remaining pellet was rehomogenized in $70 \% \mathrm{FA}$ ( $10 \mu \mathrm{L} / \mathrm{mg}$ brain tissue), incubated 45 minutes at room temperature, sonicated, and then centrifuged at 
Table 1 Description of Antibodies Used for Proximity Ligation Assay, Immunohistochemistry, Immunofluorescence, and Western Blot

\begin{tabular}{|c|c|c|c|c|}
\hline Antibody & Antigen & Species & Dilution & Supplier \\
\hline $4 \mathrm{G} 8$ & $A \beta 17-24$ & Mouse & $\begin{array}{l}1: 500 \text { (IF) } \\
1: 500 \text { (PLA) } \\
1: 1000 \text { (WB) }\end{array}$ & Signet \\
\hline 6E10 & $A \beta 1-16$ & Mouse & $1: 500$ (PLA) & Signet \\
\hline SM1341 & IAPP 7-17 & Mouse & 1:500 (PLA) & Acris \\
\hline Sc1616 & $\beta$-Actin & Goat & $1: 1000$ (WB) & Santa Cruz \\
\hline Antiserum & & & & \\
\hline A110 & mIAPP1-37 & Rabbit & 1:2000 (PLA) & Authors $^{25}$ \\
\hline A114 & hCGRP 1-37 & Rabbit & 1:500 (PLA) & Authors* \\
\hline A133 & hIAPP $20-29$ & Rabbit & $\begin{array}{l}1: 250 \text { (IHC) } \\
1: 2000 \text { (PLA) } \\
1: 1000 \text { (WB) }\end{array}$ & Authors $^{9}$ \\
\hline A169 & hproIAPP $6-13$ & Rabbit & $1: 50(\mathrm{IHC})$ & Authors $^{9}$ \\
\hline A165 & hproIAPP 46-55 & Rabbit & $1: 200(\mathrm{IHC})$ & Authors $^{9}$ \\
\hline A142 & hproIAPP 52-67 & Rabbit & 1:2000 (PLA) & Authors ${ }^{10}$ \\
\hline A159 & ApoAI 9-20 & Rabbit & 1:2000 (PLA) & Authors $^{26}$ \\
\hline A179 & Medin & Rabbit & $1: 2000$ (PLA) & Authors $^{27}$ \\
\hline
\end{tabular}

*See Supplemental Figure S2A.

ApoAI, apolipoprotein AI; hIAPP, human IAPP; hproIAPP, human proIAPP; IHC, immunohistochemistry; IF, immunofluorescence; mIAPP, mouse IAPP; PLA, proximity ligation assay; WB, Western blot.

$100,000 \times g$ for 1 hour at $4^{\circ} \mathrm{C}$. The supernatant was lyophilized and redissolved in DMSO to generate the FA fraction.

\section{Kidney}

Frozen kidney tissue was extracted in $150 \mathrm{mmol} / \mathrm{L}$ Tris- $\mathrm{HCl}$ (pH 6.8), 6\% mercaptoethanol, $12 \%$ SDS, and 30\% glycerol (SDS sample buffer) with cycles of mechanical homogenization and heating at $95^{\circ} \mathrm{C}$. The supernatant was recovered and used as negative control in Western blot.

Anonymized fresh brain tissue was from the brain bank, and formalin-fixed tissues were recovered from the amyloid archive, Uppsala University, and approved for research by the local ethical committee, Uppsala University.

\section{Western Blot Analysis}

Proteins from tissue extracts were solubilized with SDS sample buffer, separated by $6 \%$ to $12.5 \%$ tricine-SDS-PAGE, and then transferred onto a nitrocellulose membrane (Hybond-ECL) and boiled in PBS for 5 minutes. Membrane was blocked in Tween-Tris-buffered saline with $5 \%(\mathrm{w} / \mathrm{v})$ nonfat dry milk for 1 hour and then incubated with primary antibodies A133 or 4G8 diluted in Tween-Tris-buffered saline (Table 1) overnight at $4^{\circ} \mathrm{C}$. Reactivity was visualized with horseradish peroxidase-conjugated secondary antibody (Dako) and chemiluminescence detection (Immobilon).

\section{Protein Quantification}

Total protein quantification was performed in TB and FA fractions with Pierce BCA protein assay (Fischer Scientific, Gothenburg, Sweden). Digitalized images of Western blot bands were used to quantify protein levels based on optical density of all reactivity for each antibody (ImageJ software version 1.48, NIH, Bethesda, MD).

\section{In Situ PLA}

In situ PLA can be used for colocalization studies of proteins in tissue sections. The high specificity of PLA derives from a dual binding event of two primary antibodies with different species origin, to target proteins. The primary antibodies are detected with oligonucleotide-conjugated secondary antibodies (PLA probes) that generate an amplifiable circular DNA only if both target proteins are in close proximity $(<40 \mathrm{~nm}){ }^{29}$ The sensitivity derives from the up to 1300 -fold amplification of the circular DNA strand, ${ }^{30}$ which is visualized after hybridization with fluorescencelabeled oligonucleotides.

Formalin-fixed and paraffin-embedded sections $(10 \mu \mathrm{m})$ from pancreas and brain were rehydrated and pretreated with 95\% FA for 3 minutes at room temperature to expose antigens. After rinsing in $50 \mathrm{mmol} / \mathrm{L}$ Tris- $\mathrm{HCl}$ buffer with 150 $\mathrm{mmol} / \mathrm{L} \mathrm{NaCl}(\mathrm{pH} 7.4)$, pancreas sections were incubated with primary antibody pairs, IAPP antiserum (A133), and mouse anti-A $\beta$ antibody $4 \mathrm{G} 8$ or A133 and mouse anti-IAPP antibody (SM1341) (Table 1). Brain sections were incubated with mouse anti-A $\beta$ antibodies $4 \mathrm{G} 8$ or $6 \mathrm{E} 10$ mixed with antiIAPP antisera (A110, A133) or anti-proIAPP (A142). Mouse anti-A $\beta$ antibodies $4 \mathrm{G} 8$ were also used in combination with anti- $\alpha$ CGRP antiserum (A114), anti-apoA1 antiserum (A159), or anti-medin antiserum (A179) (Table 1). Primary antibody incubations were performed overnight at room

Table 2 Clinical Information on Patients

\begin{tabular}{|c|c|c|c|c|}
\hline Patient no. & Sex & $A D$ & $\begin{array}{l}\text { Duration of } \\
\text { disease } \\
\text { (years) }\end{array}$ & Diagnosis \\
\hline AD1 & M & 64 & Unknown & $A D$ \\
\hline AD2 & M & 61 & 9 & $A D$ \\
\hline AD3 & $\mathrm{F}$ & 84 & 3 & AD+Lewy body \\
\hline AD4 & $\mathrm{F}$ & 92 & 12 & $A D$ \\
\hline AD5 & M & 85 & $>10$ & $A D$ \\
\hline AD6 & M & 88 & $>10$ & $A D$ \\
\hline Non-AD1 & M & 88 & & MDC \\
\hline FTD1 & M & 70 & & FTD \\
\hline FTD2 & $\mathrm{F}$ & 61 & & FTD \\
\hline PSP & M & 70 & & $\begin{array}{l}\text { PSP + mild degenerative } \\
\text { changes of AD type }\end{array}$ \\
\hline Non-AD2 & M & 74 & & $\begin{array}{l}\text { Familial TTR amyloidosis } \\
\text { without } A D \text { diagnosis, } \\
\text { but with diffuse plaques }\end{array}$ \\
\hline T2D1 & M & 82 & 16 & $\mathrm{~T} 2 \mathrm{D}$ \\
\hline T2D2 & $\mathrm{F}$ & 78 & 5 & $\mathrm{~T} 2 \mathrm{D}$ \\
\hline T2D3 & $\mathrm{F}$ & 74 & 15 & $\mathrm{~T} 2 \mathrm{D}$ \\
\hline T2D4 & M & 68 & 10 & T2D \\
\hline
\end{tabular}

$F$, female; $M$, male; $A D$, Alzheimer disease; FTD, frontotemporal dementia; MDC, mild degenerative changes; PSP, progressive supranuclear palsy; T2D, type 2 diabetes; TTR, transthyretin amyloid. 

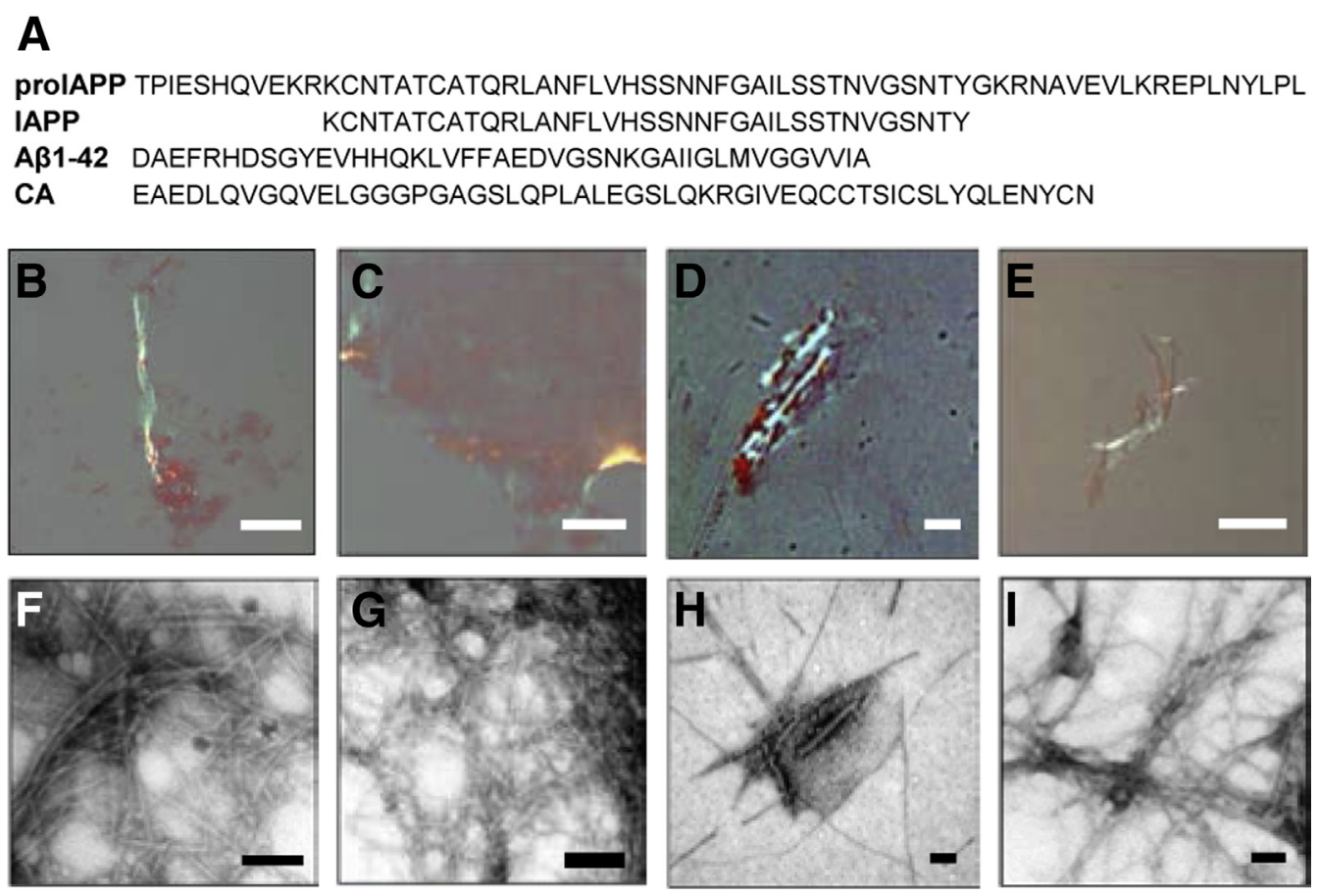

Figure 1 A: One letter code of amino acid sequences of human pro-islet amyloid polypeptide (hproIAPP) 1 to 67 , human IAPP 1 to 37 (hIAPP), A 1 to 42 , and des 31, 32 human proinsulin (CA). B-E: Three microliters of aggregates in solutions were dried on a slide and stained with Congo Red. The preparations of proIAPP (B), IAPP (C), A 1 to 42 (D), and CA (E) exhibit green birefringence when viewed in a polarization microscope. Fibrillar aggregates were placed on Formvar-coated copper grids and negatively contrasted with $2 \%$ uranyl acetate in $50 \%$ ethanol. $\mathbf{F}-\mathbf{I}$ : Long, slender amyloid-like fibrils are present in preparations of proIAPP (F), IAPP (G), A 1 to $42(\mathbf{H})$, and CA (I). Scale bars: $50 \mu \mathrm{m}(\mathbf{B}-\mathbf{E}) ; 100 \mu \mathrm{m}(\mathbf{F}-\mathbf{I})$.

temperature (Table 1). Duolink in situ PLA (Olink Bioscience, Uppsala, Sweden) was performed according to the manufacturer's protocol. Briefly, for detection of primary antibody pairs, sections were incubated for 90 minutes with oligonucleotide-conjugated anti-mouse IgG MINUS and antirabbit IgG PLUS (PLA probes) diluted 1:6 in Tris-buffered saline at $37^{\circ} \mathrm{C}$. Amplified DNA strands were detected with oligonucleotides conjugated to a fluorophore, and nuclei stained with Hoechst.

\section{Immunohistochemistry}

Formalin-fixed, paraffin-embedded mouse pancreas sections ( $6 \mu \mathrm{m}$ thick) from hIAPP transgenic mouse injected with preformed hproIAPP fibrils were rehydrated and incubated with primary antibody A169, A133, or A165 (Table 1) overnight at room temperature. Sections were rinsed in Tris-buffered saline, and reactivity was detected with alkaline phosphatase-labeled secondary antibody (Dako) and Fast red (Sigma-Aldrich). Sections were counterstained with Mayer's hematoxylin.

\section{Immunofluorescence}

Formalin-fixed, paraffin-embedded human brain sections (10 $\mu \mathrm{m}, \mathrm{AD} 5, \mathrm{AD} 6$, and non-AD2) (Table 2) were rehydrated, treated with $70 \%$ FA for 5 minutes, and then incubated with primary antibody 4G8 (Table 1) overnight at room temperature. Sections were rinsed in Tris-buffered saline, and reactivity was visualized with secondary antibody labeled with Alexa 488 nm (Invitrogen, Gothenburg, Sweden).

\section{Congo Red Staining}

Alkaline Congo Red staining was performed as previously described. ${ }^{31}$ This amyloid-specific dye stains amyloid fibrils pink and discloses green birefringence when viewed in cross-polarized light; a red fluorescence signal is detected when the material is analyzed in a fluorescence microscope at 543-nm excitation.

\section{Microscopic Analysis}

PLA and Congo-stained sections were analyzed in a Nikon Eclipse E800 confocal microscope (Nikon, Kawasaki, Japan) equipped with argon 488-nm and $\mathrm{HeNe} 543$-nm lasers.

Sections stained with Congo Red and used for quantification of amyloid were analyzed in cross-polarized light (Olympus, Stockholm, Sweden).

Fibrils were analyzed at $75 \mathrm{kV}$, with a Hitachi 7100 transmission electron microscope (Hitachi, Tokyo, Japan), and micrographs were captured with Gatan multiscan camera with Gatan digital micrograph software version 3.6.4 (Gatan, Pleasanton, CA).

\section{Statistical Analysis}

Islet amyloid frequency in $h I A P P^{+/+} m I A P P^{-/-}$mice was analyzed with Fischer's exact test, and IAPP concentrations 
Table 3 Intravenous Injection of Preformed Fibrils Produced from hproIAPP, hIAPP, and A $\beta$ Seed IAPP Amyloid in Islets of hIAPP $^{+/+}$mIAPP $^{-/-}$Transgenic Mice

\section{Total no. of}

islets in mice

No. of mice/no. with amyloid/no. \% Islets Islet of mice with of islets with with amyloid

\begin{tabular}{lllll} 
Fibril & amyloid & amyloid & amyloid & score* \\
\hline hIAPP & $7 / 5$ & $518 / 125$ & $24^{\dagger \ddagger \S}$ & $7 / 30 / 88$ \\
hproIAPP & $7 / 5$ & $382 / 59$ & $15.4^{\S}$ & $10 / 17 / 32$ \\
A & $7 / 5$ & $231 / 35$ & $15.2^{\S}$ & $4 / 8 / 23$ \\
$\mathrm{CA}$ & $6 / 2$ & $280 / 14$ & 5 & $0 / 1 / 13$ \\
$\mathrm{NaCl}$ & $7 / 2$ & $301 / 8$ & 2.6 & $0 / 2 / 6$ \\
\hline
\end{tabular}

${ }^{*}$ Coherent areas with amyloid/multiple spots of amyloid/a single spot of amyloid in an islet. Fisher's exact test was used for comparison.

${ }^{\dagger} P<0.05$, hIAPP versus $A \beta$.

$\ddagger P<0.01$, hIAPP versus hproIAPP.

${ }^{\S} P<0.001$, hIAPP, hproIAPP, and $A \beta$ versus both sodium chloride and CA.

in $\mathrm{AD}$ and non-AD patients were analyzed with unpaired, two-tailed Student's $t$-test (GraphPad Prism 6 Software, San Diego, CA). $P<0.05$ was regarded as significant.

\section{Results}

\section{Seeding and Cross-Seeding of Islet Amyloidosis}

Amyloid properties of hproIAPP, hIAPP, A $\beta$, and CA fibrils were confirmed with Congo Red staining, and all preparations exhibited green birefringence when viewed in a polarization microscope (Figure 1, B-E); typical amyloidlike fibrils were identified after negative staining with $2 \%$ uranyl acetate in 50\% ethanol and transmission electron microscopy analysis (Figure 1, F-I). After injection of preformed fibrils, animals were housed on standard chow and had free access to lard to stimulate islet amyloidogenesis for 10 months. When the animals were sacrificed, pancreas was recovered and analyzed for islet amyloid after Congo Red staining. Islet amyloid developed in 5 of 7 mice from groups injected with hproIAPP, hIAPP, or A $\beta$ fibrils; in 2 of 6 mice injected with CA fibrils; and in 2 of 7 mice injected with sodium chloride (Table 3). One animal from the CA group died during the study. The number of islets with amyloid was $2.7 \%$ and $5 \%$ in mice injected with sodium chloride or $\mathrm{CA}$, respectively $(P=0.2)$, and increased to $24.1 \%$ in mice injected with hIAPP fibrils, $15.4 \%$ in mice injected with hproIAPP fibrils, and $15.2 \%$ in mice injected with $\mathrm{A} \beta$ fibrils $(P<0.0005)$ (Table 3$)$. The amyloid consisted of IAPP in all five groups, and was primarily found perivascularly in mice seeded by hproIAPP, hIAPP, or A $\beta$ preformed fibrils (Figure 2, A-C). Amyloid deposits in control groups injected with $\mathrm{CA}$ or sodium chloride were smaller and mainly present in or in association with $\beta$ cells (Figure 2, D and E). These in vivo results strongly support that not only seeding, but also cross-seeding, is possible of local IAPP amyloid via blood.
To investigate whether hproIAPP fibrils seeded proIAPP and/or IAPP, sections from mice injected with hproIAPP fibrils were subjected to immunohistochemistry with proIAPPspecific antisera A169 and A165, and hIAPP-specific antiserum A133 (Table 1 and Figure 2, F-H), in combination with Congo Red staining (Figure 2, I-K). Because only IAPP-immunoreactivity (IR) was found in perivascular amyloid deposits (Figure 2G), these results suggest that IAPP amyloid grows through deposition of locally secreted IAPP.

Pancreata from mice injected with preformed hproIAPP $(n=3)$, hIAPP $(n=3)$, CA $(n=3)$, or A $\beta(n=3)$ fibrils and sacrificed 1 day later were all free of Congo-positive material. This ensures that the amount of fibrils given for seeding were below the detection level. Also, other organs, ie, spleen, kidney, liver, heart, or lung, recovered from mice 1 day and 10 months after fibril injection were free of amyloid, showing that no systemic amyloidosis was induced.

\section{$A \beta$ Immunoreactivity Is Not Present in Human Islet Amyloid}

Antibody-based methodology was used for colocalization studies, and to ensure the specificity of the antibodies, they were evaluated with slot blot analysis. Antiserum A133 was prepared against residues 20 to 29 of hIAPP, unique to this peptide, and it reacted with hIAPP, but lacked reactivity with haCGRP, a related peptide expressed in the central nervous system. Antiserum A110 was produced against mouse IAPP 1 to 37 (mIAPP) and reacted with both hIAPP and haCGRP. $\mathrm{A} \beta$ antibody $4 \mathrm{G} 8$ showed no reactivity with any of the IAPPrelated peptides or CGRP (Figure 3 and Table 1).

Thereafter, we used pancreas sections with islet amyloid from patients diagnosed with T2D $(n=4)$ (Table 2). Extracted material was separated on SDS-PAGE, subjected to Western blot, and the presence of $A \beta$ and IAPP was analyzed with 4G8 and A133, respectively. No A $\beta$-IR could be detected in any of the four T2D samples analyzed, whereas all samples contained IAPP-IR (Figure 4A). The pattern of A133 IR showed that IAPP was present as monomers, dimers, and trimers, and this confirmed a successful protein extraction.

We continued to investigate the possibility of $A \beta$ presence in IAPP amyloid of T2D patients, and for this, we used the highly specific and sensitive antibody-based detection method, in situ PLA. Pancreas sections from T2D patients with islet amyloid (Figure 4B) were incubated with A133 in combination with 4G8, but without generating any PLA signal (Figure 4C). As a positive control, A133 was combined with an anti-IAPP mouse monoclonal antibody (SM1341), and this generated IAPP signals (Figure 4D).

\section{IAPP Immunoreactivity Is Detected in Human Brain}

Next, we investigated whether IAPP and $A \beta$ colocalize in human brain. Tissue samples from temporal cortex from $\mathrm{AD}$ patients (AD1- to 4) and age-matched non-AD patients diagnosed with frontotemporal dementia $(n=2)$, 

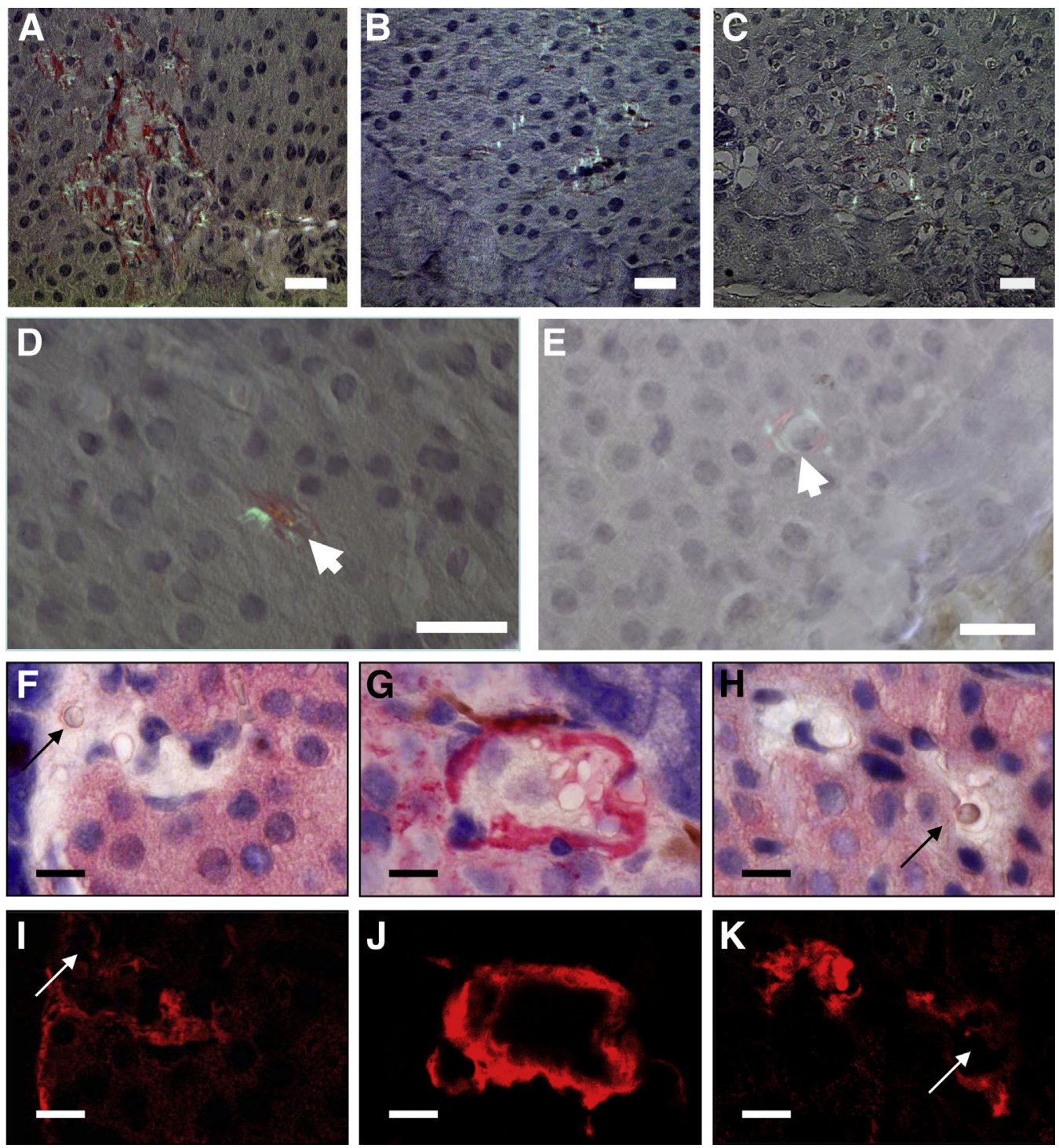

Figure 2 A-C: Intravenous injection of preformed human pro-islet amyloid polypeptide (hproIAPP; A), hIAPP 1 to 37 (B), and A 1 to 42 (C) fibrils seeded perivascular islet amyloid in hIAPP transgenic mice. D and E: Intravenous injection with preformed CA (D) fibrils or sodium chloride (E) result in less extensive aggregates without direct vascular association. Sections were stained for amyloid with Congo Red and viewed in a polarization microscope; amyloid was detected as green or pink material. In $\mathbf{D}$ and $\mathbf{E}$, the white arrowhead points to the cell nucleus. $\mathbf{F}-\mathbf{K}$ : Consecutive sections from mice injected with preformed hproIAPP fibrils were subjected to immunohistochemistry with antisera A169 (produced against the N-terminal processing site of hproIAPP; $\mathbf{F}$ ), A133 (residues 20 to 29 of hIAPP 1 to 37) (G), or A165 (produced against the C-terminal processing site of hproIAPP) (H) in combination with Congo Red staining $(\mathbf{I}-\mathbf{K}) . \mathbf{G}$ and $\mathbf{J}$ : A133 reactivity in $\mathbf{G}$ corresponds to the perivascular amyloid in J, whereas neither A169 nor A165, both specific for proIAPP, reacted with perivascular amyloid. All three antibodies label $\beta$ cells. Primary antibodies were detected with alkaline phosphatase labeled secondary antibody and visualized with Fast red. Sections were counterstained with Mayer's hematoxylin. The black arrows point to vascular amyloid not detected by specific antisera A169 and A165, respectively (F and $\mathbf{H})$; white arrows point to vascular amyloid (I and $\mathbf{K})$. Scale bars: $20 \mu \mathrm{m}(\mathbf{A}-\mathbf{E}) ; 10 \mu \mathrm{m}(\mathbf{F}-\mathbf{K})$.

progressive supranuclear palsy $(n=1)$, and with no neurological diagnosis $(n=1)$ (Table 2) were extracted with Tris-HCl buffer ( $\mathrm{pH}$ 7.4) followed by extraction in FA to obtain soluble and insoluble brain fractions, respectively. Supernatants were separated by SDS-PAGE and subjected to Western blot analysis with A133 and 4G8 for detection of IAPP and $A \beta$, respectively. IAPP reactivity was detected in Tris-HCl buffer and the FA fraction of all samples analyzed. Tris-HCl buffer fractions contained mainly high molecular weight material approximately 16-mer IAPP, whereas FA fractions contained a 6-mer band (Figure 5A). After extended exposure of the Western blot, the FA fraction exhibited a ladder-like pattern where 3-, 6-, and 8-mer IAPP were the most frequent sizes (Figure 5B).

When total IAPP content was determined in the FA fraction and normalized to total protein content, it was shown that AD samples contained 1.4 times higher IAPP concentrations than samples from non-AD patients (Figure 5C). As expected, more $A \beta$ was detected in $A D$ samples than in non-AD samples (not shown).

Human kidney extract from a patient with amyloid lightchain amyloidosis was used as negative control for Western 


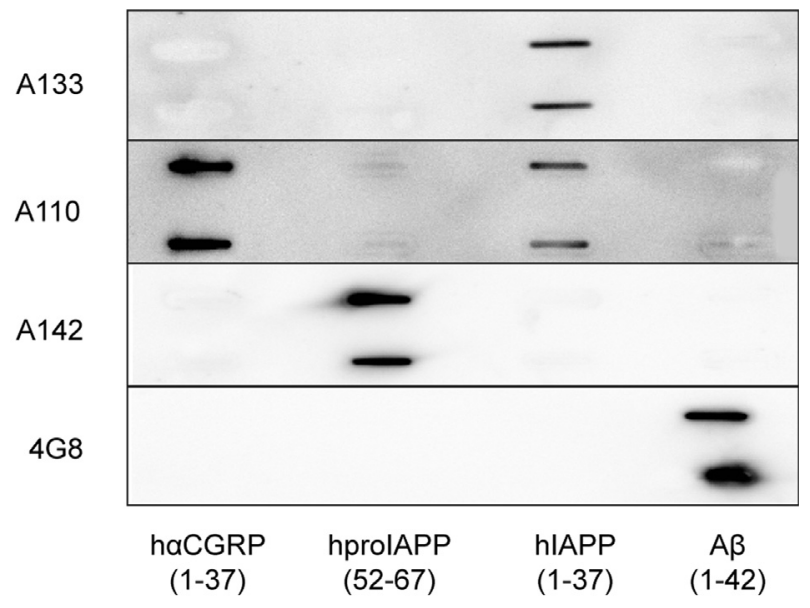

Figure 3 Reactivity of islet amyloid polypeptide (IAPP) antisera A133, $\mathrm{A} 110$, and $\mathrm{A} 142$, as well as anti-A $\beta$ (4G8) was determined with slot blot analysis against human $\alpha$-CGRP, hproIAPP residues 52 to 67 , hIAPP 1 to 37 , and $A \beta 1$ to 42 . A133 produced against residues 20 to 29 of hIAPP reacts only with hIAPP 1 to 37 and does not cross-react with the related peptide $\alpha$-CGRP. This is in contrast to A110 that is produced against mIAPP 1 to 37 and which reacts with hIAPP1 to 37 and also with $\alpha$-CGRP. A142 is produced against a 16 -residue-long peptide that corresponds to the $\mathrm{C}$-terminal flanking peptide of hproIAPP, and in this analysis, A142 reactivity is restricted to this peptide. None of IAPP antisera reacts with $A \beta 1$ to 42 , and $4 \mathrm{G} 8$ reaction is restricted to $A \beta 1$ to 42 .

blotting with A133, and this did not give rise to any IAPP reaction (Supplemental Figure S1).

\section{IAPP Colocalizes with $A \beta$ in Cerebral and Cerebrovascular Amyloid Deposits}

The increased IAPP-IR in the FA fraction of AD brains suggests that IAPP may be present in amyloid plaques. Therefore, we continued to investigate the relationship between $A \beta$ and IAPP in brain of AD patients and for this we went back to the detection method in situ PLA.

A combination of anti-A $\beta$ antibody $4 \mathrm{G} 8$ with anti-IAPP antiserum A133 (4G8/A133) (Table 1) generated PLA signals in AD temporal cortex sections. Congo Red staining of adjacent sections confirmed colocalization of the PLA signals with amyloid in senile plaques and vessel walls (Figure 6, A and D). The fluorescent PLA signal was scattered throughout the plaque area and present in all congophilic plaques (Figure 6, B and $\mathrm{E}$ ), whereas the PLA signal in vessel walls was unevenly distributed (Figure 6, C and F).

When 4G8 was combined with A110 (4G8/A110), the PLA signal increased in both senile plaques and vessel walls compared to 4G8/A133 (Figure 7, A and B). This could result from increased antibody binding because A110 is produced against IAPP 1 to 37 and is expected to contain antibodies directed against more epitopes than A133. Another reason could be cross-reactivity with CGRP, because slot blot analysis revealed that antiserum A110 cross-reacts with h $\alpha$ CGRP. Therefore, antiserum A114 produced against and specific for a peptide corresponding to residues 20 to 29 of
haCGRP (Supplemental Figure S2A) was included and combined with 4G8 in PLA. The result thereof showed few PLA signals for 4G8/A114 (Supplemental Figure S2, B and C), and we conclude that PLA signal from 4G8/A110 originates primarily from IAPP reactivity. A combination of A142 with 4G8 was used to search for proIAPP reactivity in AD brain sections. Signals were obtained for 4G8/A142 and had the same distribution pattern as 4G8/A133 and 4G8/ A110 (Figure 7C). The area occupied by PLA signals per plaque area was quantified in sections from one AD case to $13.3 \pm 3.4 \%(n=19)$ for $4 \mathrm{G} 8 / \mathrm{A} 133,19.9 \pm 5.9 \%(n=16)$ for $4 \mathrm{G} 8 / \mathrm{A} 110$, and $5.1 \pm 3.3 \%(n=14)$ for $4 \mathrm{G} 8 / \mathrm{A} 142$ (Figure $7 \mathrm{G}$ ). Also, anti-A $\beta$ antibody $6 \mathrm{E} 10$ was used in combination with A133 (6E10/A133), and this generated overall fewer PLA signals per plaque area compared to 4G8/ A133 (Supplemental Figure S3). It may be that the epitope for $6 \mathrm{E} 10$ was covered when $\mathrm{A} \beta$ formed aggregates or $\mathrm{N}$-terminal fragmentation of the $\mathrm{A} \beta$ peptide lead to loss of the epitope for 6E10.

\section{$A \beta$ and IAPP Colocalize in Diffuse Plaques}

Consecutive cortical brain sections from two patients (AD 5 and 6) were subjected to PLA with 4G8/A133,
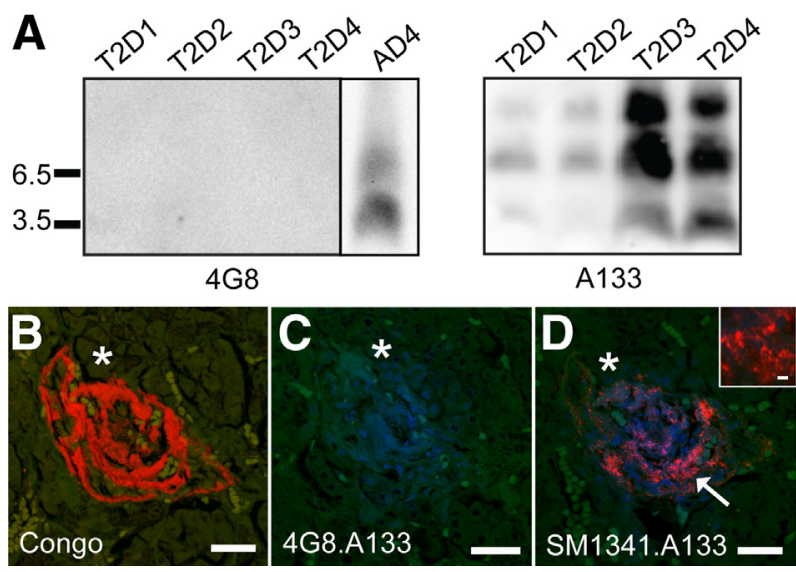

Figure 4 Amyloid-beta $(A \beta)$ reactivity is not present in islet amyloid extracts from patients with type II diabetes (T2D). A: Sections from four pancreases with confirmed islet amyloid were used for protein extraction and separation on $6 \%$ to $12.5 \%$ tricine-SDS-PAGE. Immunoblotting with $4 \mathrm{G} 8$ fails to detect $A \beta$ in any of the four samples, whereas A133 identifies monomers, dimers, and trimers of IAPP in the same material. FA brain extract from the AD4 patient was included as a positive control for 4G8. Colocalization of $A \beta$ and islet amyloid polypeptide (IAPP) cannot be detected in sections with islet amyloid from patients with T2D. B: The presence of islet amyloid was visualized by Congo Red staining. C: Antibodies $4 \mathrm{G} 8$ and $\mathrm{A} 133$ were used for proximity ligation assay (PLA) to investigate whether $A B$ was present in islet amyloid. This combination does not give rise to any PLA signal. D: As a positive PLA control, two different IAPP antibodies were used (SM1341 and A133), and this combination results in a clear PLA signal. Consecutive sections were used, and asterisks denote the corresponding region. Amyloid is identified by Congo Red that fluoresces red at $543 \mathrm{~nm}$, and the PLA signal appears as red fluorescent dots at $543 \mathrm{~nm}$. Arrow in $\mathbf{D}$ points at the region enlarged in the inset. Scale bars: $30 \mu \mathrm{m}$ (B-D, main images); $2 \mu \mathrm{m}$ (D, inset). 


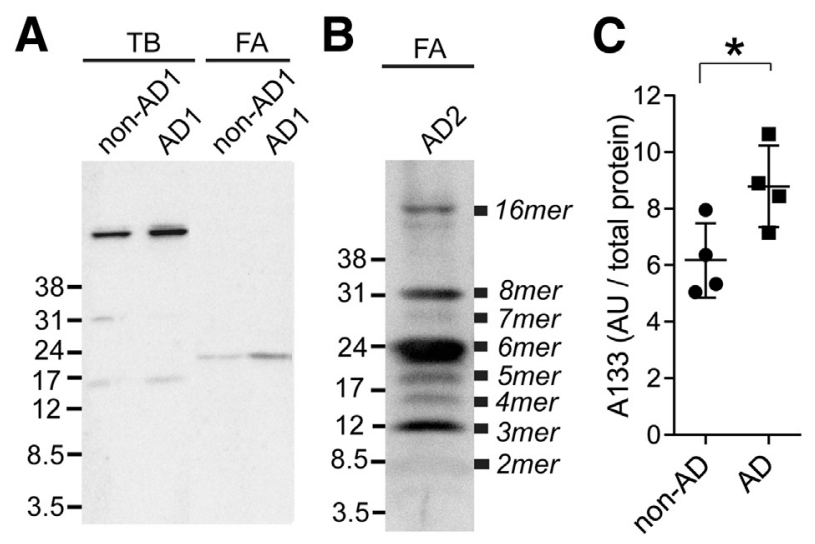

Figure 5 Islet amyloid polypeptide (IAPP) reactivity is present in human brain extracts. Tris buffer (TB) and formic acid (FA) extracts of human temporal cortex from an Alzheimer disease (AD) patient (AD1) and non-AD patient (non-AD1) were resolved in $6 \%$ to $12.5 \%$ tricine-SDS-PAGE and immunoblotted with IAPP antiserum A133. A: After separation of the TB fractions, bands with a main molecular size approximately 16-mer of IAPP appear in both $A D$ and non-AD extracts. In the FA fraction, a band corresponding to 6-mer of IAPP appears. B: More extensive exposure multiple bands can be seen in the FA fraction with a ladder like pattern corresponding to dimers up to approximately 16-mer of IAPP, and the most common IAPP species in the FA fraction are 3-, 6-, and 8-mer, whereas monomeric IAPP is not identified. C: Higher levels of IAPP are detected in the brain of AD patients. FA extract from human temporal cortex from $A D$ patients $(n=4)$ and non-AD patients $(n=4)$ were resolved in $6 \%$ to $12.5 \%$ tricine-SDS-PAGE, and immunoblotted with A133. The total IAPP immunoreactivity was measured and normalized against total protein content, and determined to be $8.8 \pm 1.4$ in $A D$ patients and $6.2 \pm 1.3$ in non-AD patients. ${ }^{*} P<0.05 \mathrm{AD}$ patients versus non-AD patients. $n=4$ (AD patients, C); $n=4$ (non-AD patients, C).

immunofluorescence (IF) with 4G8 and Congo Red staining. The numbers of plaques were determined to $64 \pm 12$ / $\mathrm{mm}^{2}$ after PLA, $65 \pm 13 / \mathrm{mm}^{2}$ after IF, and $36 \pm 9 / \mathrm{mm}^{2}$ after Congo Red staining (Figure $7 \mathrm{H}$ ), suggesting that IAPP is present in diffuse noncongophilic plaques. To test this, PLA was performed on brain tissue from a patient not diagnosed with $\mathrm{AD}$ (non-AD2), but where a high number of diffuse plaques had been identified. The cortical noncongophilic plaques in non-AD2 were identified with PLA (4G8/A133) and IF (4G8) (Figure 7, I-K).

\section{Control Analysis}

To secure the results from the PLA assay, extensive control analyses were performed. As positive control for the PLA technique, 4G8 was combined with antiserum A159 reactive with known plaque component apoA $1^{32}$ and consequently generated PLA signals in the senile plaques (Figure 7D). The signal per plaque area was calculated to be $12.5 \pm 2.8 \%$ $(n=17$ ) for $4 \mathrm{G} 8 / \mathrm{A} 159$ (Figure $7 \mathrm{G}$ ), ie, a signal frequency similar to IAPP detected with 4G8/A133.

Consistent with observations from the 6E10/A133 combination, 6E10/A159 also generated fewer PLA signals in the plaques than 4G8/A159 (not shown). Negative controls included the substitution of primary antibodies raised in rabbit with antiserum A179 reactive with plaque-unrelated amyloid peptide medin (4G8/A179) (Figure 7E) or omission of A133 (4G8/X) (Figure 7F). Calculation of PLA signal area per plaque after 4G8/A179 was determined to be $0.7 \pm 0.8 \%(n=8)$, and no PLA signal occurred when one primary antibody was omitted (Figure $7 \mathrm{G}$ ).

\section{Discussion}

A single i.v. injection of preformed amyloid-like fibrils produced from hproIAPP, hIAPP, or A $\beta$ and 10 months on high-fat feeding stimulated formation of islet amyloid in hIAPP transgenic mice. Not only the number of mice with islet amyloid was higher, but also the number of islets with amyloid was significantly increased from $2.7 \%$ and $5 \%$ in mice injected with sodium chloride and CA, respectively, to $24 \%$ in mice injected with hIAPP fibrils, and $15 \%$ in mice injected with hproIAPP or $A \beta$ fibrils. These results suggest that the local islet amyloid can be seeded by circulating amyloid seeds, and the efficiency depends on structural similarity between seed and amyloid precursor.

Islet amyloidogenesis still needs to be explained, but the process includes both intracellular ${ }^{18-20}$ and extracellular amyloid growth. ${ }^{33,34}$ Probably, the two pathways take place in parallel and are to some extent interdependent. In AD, A $\beta$ is generated by cleavage of $A \beta P P$ in early endosomes, and $\mathrm{A} \beta$ can leave the cells through exosomal transport. ${ }^{35}$ That exosomes play a role in amyloid formation was shown in 5XFAD transgenic mice when chemical blockade of exosome formation with GW4869 resulted in decreased A $\beta$ plaques formation. ${ }^{36}$ IAPP amyloid formed in $\beta$ cells can become extracellular after apoptosis if not cleared by macrophages, or if IAPP amyloid is released in association with exosomes from $\beta$ cells. The effective seeding of IAPP amyloid in islets after injections of preformed IAPP fibrils supports the presence of extracellular amyloid as an important mechanism for amyloid growth.

We have earlier shown that incomplete or absent posttranslational processing of proIAPP to IAPP can trigger intracellular amyloid formation. ${ }^{6}$ In transmission electron microscopy analysis of human and hIAPP mouse islets transplanted under the kidney capsule of nude mice, a fibrillar aggregate appeared within the halo region of secretory granules, and the use of proIAPP-specific antisera enabled us to show that these fibrils at least in part consisted of proIAPP. ${ }^{10}$ Immunohistochemistry performed on amyloid deposited in mouse injected with proIAPP fibrils revealed only IAPP-IR, which indicates that after seeding, amyloid had grown through locally secreted IAPP. IAPP is cleaved from the precursor proIAPP, and circular dichroism analysis of proIAPP and IAPP identified few ordered secondary structure elements, with only minor discrepancies between the peptides. ${ }^{37}$ In an in vitro study on proIAPP aggregation, it was shown that proIAPP formed amyloid fibrils, but the capacity was suppressed by the 

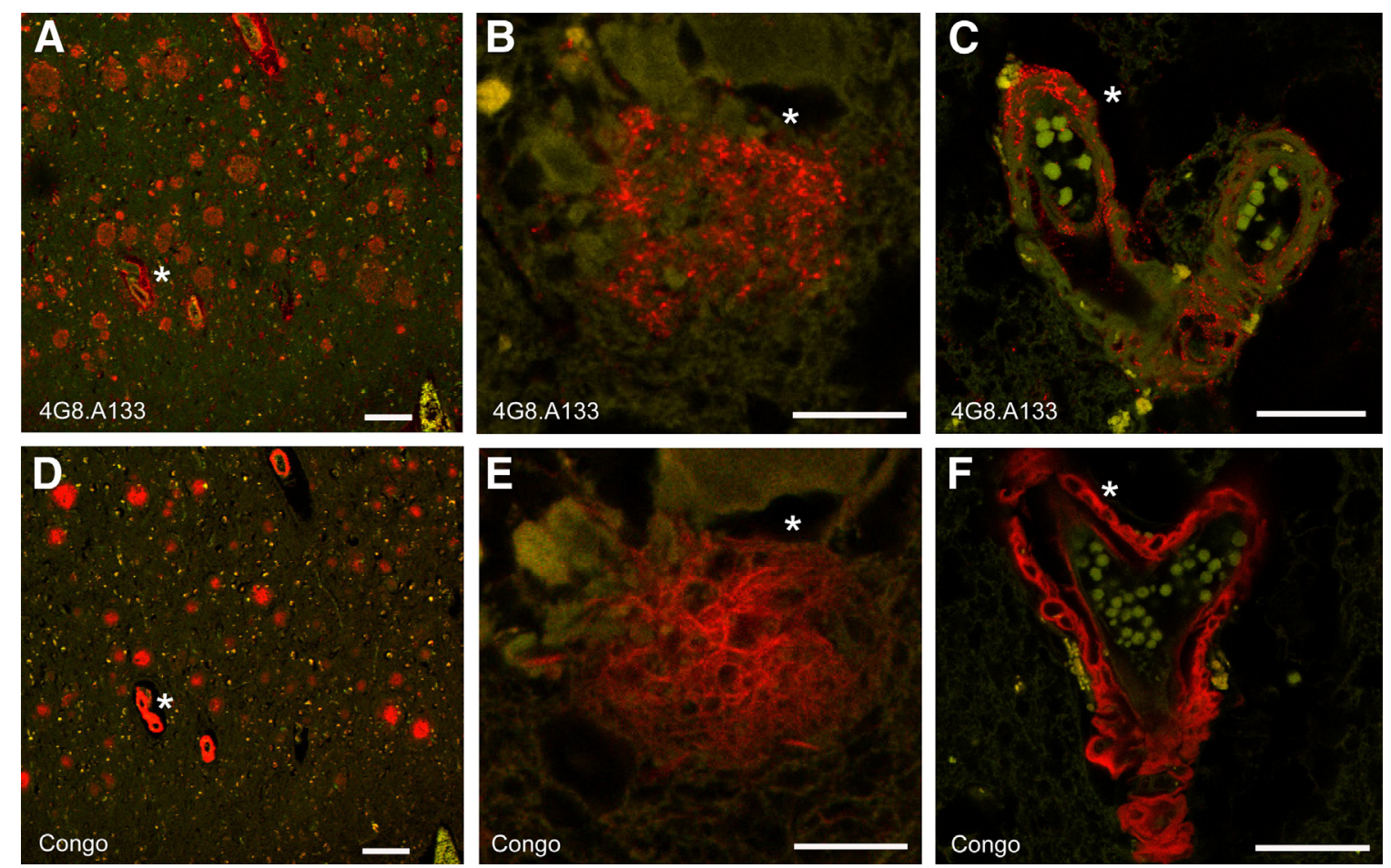

Figure 6 Amyloid-beta (A $\beta$ ) and islet amyloid polypeptide (IAPP) colocalize in cerebral amyloid deposits and in cerebral vascular amyloid in patients with Alzheimer disease (AD). Proximity ligation assay (PLA) was performed with $4 \mathrm{G} 8$ and A133 on cortical brain sections (A-C), and Congo Red was used to identify amyloid in an adjacent section (D-F). A and D: At low magnification, the PLA signal (A) and amyloid (D) show an overall consistency. B and E: The PLA signal is limited to the cortical plaques (B) and in accord with Congo Red (E). C and F: Also, A $\beta$ and IAPP colocalize (C) in amyloid (F) present in tunica media and appear in clusters. PLA signal appears as red fluorescent dots when viewed at $543 \mathrm{~nm}$; amyloid was identified by Congo Red that fluoresces red at $543 \mathrm{~nm}$. Asterisks denote corresponding regions in image pairs. Scale bars: $150 \mu \mathrm{m}$ (A and $\mathbf{D}) ; 30 \mu \mathrm{m}(\mathbf{B}, \mathbf{C}, \mathbf{E}$, and $\mathbf{F})$.

propeptides. $^{38}$ The three-dimensional structure for proIAPP is not resolved, but the model on IAPP protofilament formation proposed by Kajava et $\mathrm{al}^{39}$ does not include the $11 \mathrm{~N}$-terminal residues of IAPP in the stacking of monomers. It is likely that proIAPP aggregates adopt a structure, at least partially identical to IAPP with the capacity to serve as an initiation point for IAPP fibrillar growth through incorporation of IAPP secreted from $\beta$ cells.

The aa sequence is critically important for amyloid fibril formation. ${ }^{40}$ Sequence alignment of IAPP and A $\beta 1$ to 40 showed that the two peptides share almost $50 \%$ similarity, a characteristic that increases in regions essential for fibrillogenesis. In in vitro studies on cross-seeding, $A \beta 1$ to 40 fibrils efficiently seeded IAPP in solution, whereas IAPP fibrils' ability to seed $A \beta$ in solution was low and reached only $2 \%$ of the efficiency measured for $A \beta$ fibrils. ${ }^{17}$ In our study, injection of $A \beta$ seeds in hIAPP transgenic mice potentiated IAPP amyloid deposition to the same level as injection of proIAPP fibrils. However, no $\mathrm{A} \beta$ reactivity could be detected in deposited amyloid even when the highly sensitive PLA methodology was applied (not shown).

$\mathrm{A} \beta \mathrm{PP}$ is widely expressed, and $\mathrm{A} \beta \mathrm{PP}$ as well as $\beta$ - and $\gamma$-secretases, essential for $A \beta$ production, are all expressed by $\beta$ cells. ${ }^{41}$ In earlier studies, it has been shown that injection of
$\mathrm{AD}$ brain extracts can be used for transmission of cerebral $\mathrm{A} \beta$ amyloid and cerebral amyloid angiopathy in primates and A $\beta P$ P transgenic mice, ${ }^{42-45}$ although injection of preformed synthetic $A \beta 1$ to 40 or $A \beta 1$ to 42 fibrils was less efficient. ${ }^{46,47}$ The detection of murine and human $A \beta 1$ to 40 and 1 to 42 coaggregates in brain amyloid deposits formed in transgenic mice expressing the human A $\beta \mathrm{PP}$ V717I London mutation ${ }^{48}$ provides evidence that mouse A $\beta P$ P can be processed into A $\beta$. Therefore, one can consider that necessary conditions for $A \beta$ fibrillation (synthesis and processing) are met in the transgenic hIAPP mouse, but despite this, mice injected with $A \beta$ fibrils developed only IAPP amyloid, and no A $\beta$-IR (4G8) (Table 1) was detected in islet amyloid deposits. However, in an attempt to elucidate the mechanism for i.p. induction of cerebral $A \beta$-amyloid in mice, Eisele et $\mathrm{al}^{49}$ used transgenic mice from the R 1.40 strain. ${ }^{50}$ Animals from this strain express human $\mathrm{A} \beta \mathrm{PP}$ in the brain and also to some extent in peripheral tissues. Two i.p. injections of $A \beta$ brain extract lead to cerebral amyloid 10 months later, a condition that continued to progress. Despite a peripheral expression of $\mathrm{A} \beta \mathrm{PP}$, these animals never developed $\mathrm{A} \beta$ amyloid outside the brain. This result points to a more complex mechanism for $A \beta$ seeding, and the lack of deposited $A \beta$ in islet amyloid in our mouse model may depend on low or no $A \beta$ production in peripheral tissue. 

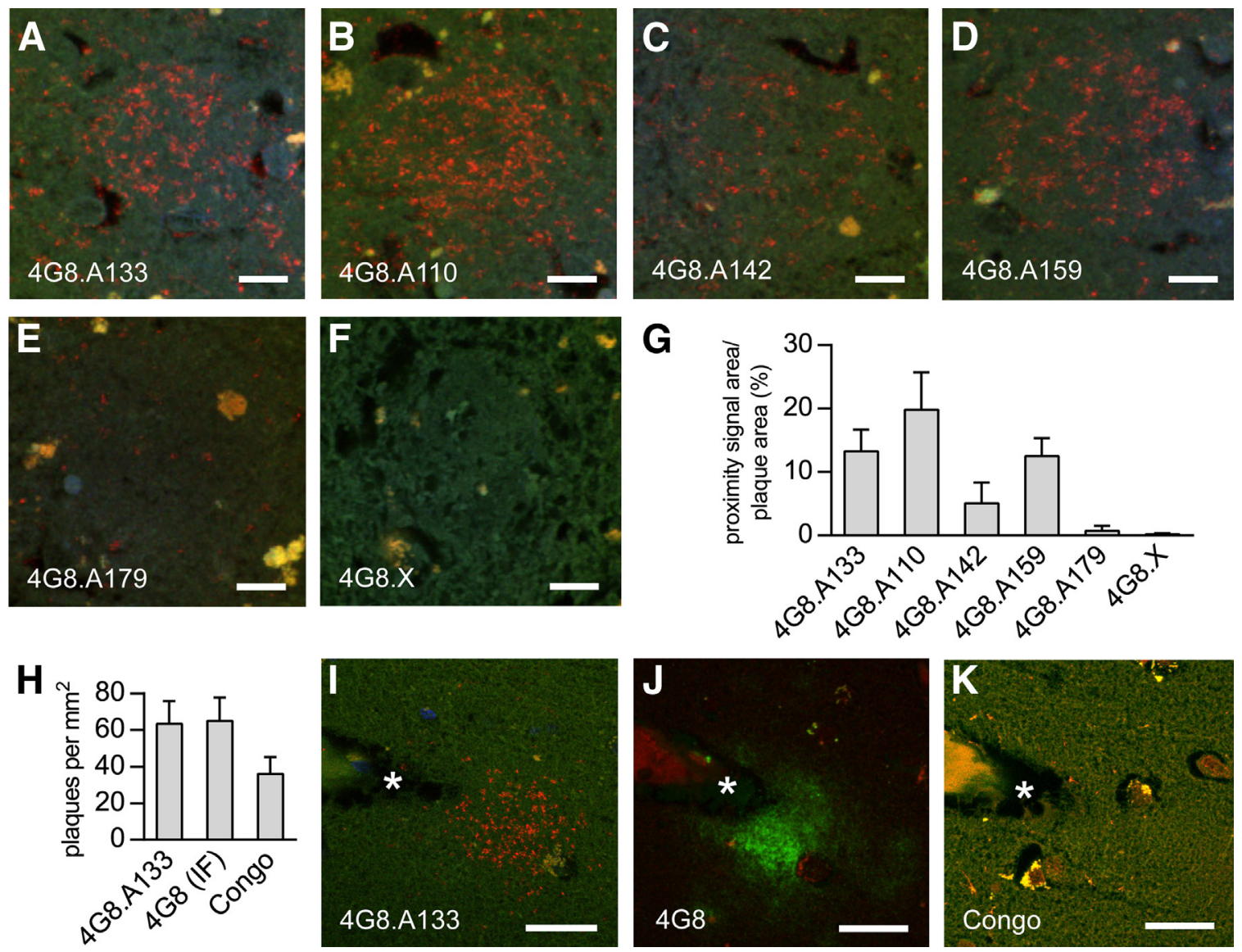

Figure 7 Pro-islet amyloid polypeptide (proIAPP) and apoA1 colocalize with amyloid-beta (A $\beta$ ) in cortical plaques from brain of Alzheimer disease (AD) patients. A-C: Proximity ligation assay (PLA) with 4G8 in combination with A133 (A), A110 (B), or A142 (C) were performed on sections from AD patients. G: The PLA signal area was determined to $13.3 \pm 3.4 \%$ for $4 \mathrm{G} 8 . A 133,19.9 \pm 5.9 \%$ for 4G8.A110, and $5.1 \pm 3.3 \%$ for 4G8.A142. Generation of a PLA signal by A142 when combined with $4 \mathrm{G} 8$ supports the presence of proIAPP in the plaques. As a step in evaluation of the PLA method, several antibodies were included. D: Antiserum A159, produced against a synthetic peptide corresponding to residues 9 to 20 of human apoA1, was included as a positive control. When PLA is performed with A159 in combination with 4G8, the obtained signals correspond to $12.5 \pm 2.8 \%$ PLA signal area per plaque area. This is similar to that generated by $\mathrm{A} 133$ and 4G8. Also, A179 was included, and this antiserum is produced against the amyloid peptide medin and not shown to be present in AD plaques. E: When A179 is combined with 4G8, almost no signal is generated $(0.7 \pm 0.8 \%)$. F: For negative control, brain section was incubated with $4 \mathrm{G} 8$ only, and amplification of the reaction was performed with both oligonucleotide-labeled secondary antibodies. This did not generate PLA signal. A $\beta$ and IAPP colocalize in noncongophilic diffuse plaques. Consecutive cortical brain sections from two AD patients were subjected to PLA with 4G8 and A133, and IF with 4G8 and Congo Red staining. H: The numbers of plaques $/ \mathrm{mm}^{2}$ were determined to be $64 \pm 12$ after PLA, $65 \pm 13$ after IF, and $36 \pm 9$ after Congo Red staining. I-K: To examine whether PLA signal occurs in diffuse plaques, sections from a non-AD2 patient were incubated with 4G8/A133. PLA signal (I) occur in diffuse plaques labeled with $4 \mathrm{G} 8(\mathbf{J})$, but do not stain with Congo Red (K). PLA signal appears as red fluorescent dots at $543 \mathrm{~nm}$ and $4 \mathrm{G} 8$ immunofluorescence as green at $488 \mathrm{~nm}$. Asterisks denote a similar region in consecutive sections. Scale bars: $10 \mu \mathrm{m}(\mathbf{A}-\mathbf{F}) ; 30 \mu \mathrm{m}(\mathbf{I}-\mathbf{K})$.

Miklossy et $\mathrm{al}^{51}$ reported the presence of $\mathrm{A} \beta$ in islets of Langerhans using immunofluorescence and showed 4G8 reactivity throughout the islet amyloid in a patient with T2D. However, they did not detect low molecular weight $A \beta$ in pancreas from T2D patients in Western blot. Initially, we tried to use immunofluorescence and optimized antigenic retrieval for carrying out the histological analysis of $A \beta$ in islet amyloid, but without any success. Taken together, our results obtained with the much more sensitive and specific PLA methodology and Western blot do not support colocalization of A $\beta$ in IAPP amyloid in islets of Langerhans in patients with $\mathrm{T} 2 \mathrm{D}$.

Interestingly, we identified IAPP in brain extracts from the four AD patients. Significantly less IAPP was found in samples from four non-AD patients. Jackson et $\mathrm{al}^{52}$ have recently reported IAPP immunoreactivity in A $\beta$ amyloid. With the aid of PLA, we showed that IAPP and A $\beta$ colocalize and are distributed throughout the senile plaque and also together with deposits present in the media of the vessel wall. As pointed out, the PLA signal requires that the two different antibodies bind with a distance $<40 \mathrm{~nm}$, showing that $\mathrm{A} \beta$ and IAPP deposits are mixed.

Our PLA results show that IAPP and A $\beta$ colocalize within diffuse and dense plaques and also within amyloid deposits present in the vessel wall. The relationship between dense core plaques and diffuse plaques are not fully established. Following the amyloid hypothesis, ${ }^{53}$ where diffuse plaques mature into dense plaques, we suggest that IAPP is already present early during the aggregation process before the aggregates obtained their amyloid tinctorial and optical properties. 
It is not clear whether IAPP found in brain is locally produced or derives from the pancreatic $\beta$ cells. However, multiple reports describe IAPP expression in brain of rat, ${ }^{54,55}$ chicken, ${ }^{56}$ and primates. ${ }^{57}$ Tight junctions in the endothelium of the blood-brain barrier limit interchange of substances between the brain and periphery, but in the area of circumventricular organs with a fenestrated endothelium $^{58}$ permeability is higher. However, IAPP has been found to cross the blood-brain barrier, ${ }^{59}$ and inflammatory cytokines can change blood-brain barrier integrity. ${ }^{60}$ Interestingly, the AD2 patient who showed the lowest level of IAPP in the FA fraction was diagnosed with AD at 52 years of age (Table 2) and with T2D 12 years earlier. Initially, blood glucose was controlled with oral antidiabetic drugs, but as the disease progressed, the need for treatment increased, and insulin was required during the last 6 years of life. The need for insulin treatment indicates that no or only a small number of $\beta$ cells remained, with expected low production of both insulin and IAPP, and consequently, little IAPP to recruit from plasma to $A \beta$ amyloid. None of the other AD and non-AD cases were diagnosed with diabetes.

In summary, we show for the first time that formation of local IAPP amyloid can be accelerated by hematogenous seed of synthetic IAPP and proIAPP fibrils. We also show that heterologous seeding with $A \beta$ fibrils is possible. From our studies of patient material, we have found that islet IAPP amyloid does not recruit $A \beta$, but that cerebral $A \beta$ amyloid contains IAPP. Seeding of IAPP with preformed fibrils of IAPP shows that homologous seeding is more effective than the heterologous seeding of IAPP with A $\beta$. Although there is a wealth of knowledge concerning formation of amyloid fibrils in vitro, very little is known as to how different forms of amyloid proteins interact and how amyloid is initiated in vivo. Cross-seeding by other amyloid aggregates or perhaps by other types of aggregates ${ }^{61,62}$ offers one possible mechanism for initiation of amyloid formation. Interactions between amyloid and other aggregation-prone proteins may be of great importance in development of protein misfolding diseases.

\section{Supplemental Data}

Supplemental material for this article can be found at http://dx.doi.org/10.1016/j.ajpath.2014.11.016.

\section{References}

1. Westermark P, Wernstedt C, Wilander E, Hayden DW, O'Brien TD, Johnson KH: Amyloid fibrils in human insulinoma and islets of Langerhans of the diabetic cat are derived from a neuropeptide-like protein also present in normal islet cells. Proc Natl Acad Sci U S A 1987, 84:3881-3885

2. Westermark P, Andersson A, Westermark GT: Islet amyloid polypeptide, islet amyloid, and diabetes mellitus. Physiol Rev 2011, 91: $795-826$
3. Marzban L, Soukhatcheva G, Verchere CB: Role of carboxypeptidase $\mathrm{E}$ in processing of pro-islet amyloid polypeptide in $\beta$-cells. Endocrinology 2005, 146:1808-1817

4. Huang CJ, Lin CY, Haataja L, Gurlo T, Butler AE, Rizza RA, Butler PC: High expression rates of human islet amyloid polypeptide induce endoplasmic reticulum stress mediated beta-cell apoptosis, a characteristic of humans with type 2 but not type 1 diabetes. Diabetes 2007, 56:2016-2027

5. Hull RL, Zraika S, Udayasankar J, Aston-Mourney K, Subramanian SL, Kahn SE: Amyloid formation in human IAPP transgenic mouse islets and pancreas, and human pancreas, is not associated with endoplasmic reticulum stress. Diabetologia 2009, 52 : 1102-1111

6. Guardado-Mendoza R, Davalli AM, Chavez AO, Hubbard GB, Dick EJ, Majluf-Cruz A, Tene-Perez CE, Goldschmidt L, Hart J, Perego C, Comuzzie AG, Tejero ME, Finzi G, Placidi C, La Rosa S, Capella C, Halff G, Gastaldelli A, DeFronzo RA, Folli F: Pancreatic islet amyloidosis, beta-cell apoptosis, and alpha-cell proliferation are determinants of islet remodeling in type- 2 diabetic baboons. Proc Natl Acad Sci U S A 2009, 106:13992-13997

7. Rivera JF, Costes S, Gurlo T, Glabe CG, Butler PC: Autophagy defends pancreatic beta cells from human islet amyloid polypeptideinduced toxicity. J Clin Invest 2014, 124:3489-3500

8. Kim J, Cheon H, Jeong YT, Quan W, Kim KH, Cho JM, Lim YM, Oh SH, Jin SM, Kim JH, Lee MK, Kim S, Komatsu M, Kang SW, Lee MS: Amyloidogenic peptide oligomer accumulation in autophagy-deficient beta cells induces diabetes. J Clin Invest 2014, $124: 3311-3324$

9. Paulsson JF, Westermark GT: Aberrant processing of human proislet amyloid polypeptide results in increased amyloid formation. Diabetes 2005, 54:2117-2125

10. Paulsson JF, Andersson A, Westermark P, Westermark GT: Intracellular amyloid-like deposits contain unprocessed pro-islet amyloid polypeptide (proIAPP) in beta cells of transgenic mice overexpressing the gene for human IAPP and transplanted human islets. Diabetologia 2006, 49:1237-1246

11. Plassman BL, Langa KM, Fisher GG, Heeringa SG, Weir DR, Ofstedal MB, Burke JR, Hurd MD, Potter GG, Rodgers WL, Steffens DC, Willis RJ, Wallace RB: Prevalence of dementia in the United States: the aging, demographics, and memory study. Neuroepidemiology 2007, 29:125-132

12. Glenner GG, Wong CW: Alzheimer's disease and Down's syndrome: sharing of a unique cerebrovascular amyloid fibril protein. Biochem Biophys Res Commun 1984, 122:1131-1135

13. Masters CL, Simms G, Weinman NA, Multhaup G, McDonald BL, Beyreuther K: Amyloid plaque core protein in Alzheimer disease and Down syndrome. Proc Natl Acad Sci U S A 1985, 82:4245-4249

14. Walter J, Kaether C, Steiner H, Haass C: The cell biology of Alzheimer's disease: uncovering the secrets of secretases. Curr Opin Neurobiol 2001, 11:585-590

15. Friedrich RP, Tepper K, Ronicke R, Soom M, Westermann M, Reymann K, Kaether C, Fandrich M: Mechanism of amyloid plaque formation suggests an intracellular basis of Abeta pathogenicity. Proc Natl Acad Sci U S A 2010, 107:1942-1947

16. Takahashi RH, Milner TA, Li F, Nam EE, Edgar MA, Yamaguchi H, Beal MF, Xu H, Greengard P, Gouras GK: Intraneuronal Alzheimer abeta42 accumulates in multivesicular bodies and is associated with synaptic pathology. Am J Pathol 2002, 161:1869-1879

17. O'Nuallain B, Williams AD, Westermark P, Wetzel R: Seeding specificity in amyloid growth induced by heterologous fibrils. J Biol Chem 2004, 279:17490-17499

18. Andreetto E, Yan LM, Tatarek-Nossol M, Velkova A, Frank R, Kapurniotu A: Identification of hot regions of the Abeta-IAPP interaction interface as high-affinity binding sites in both cross- and self-association. Angew Chem Int Ed Engl 2010, 49:3081-3085

19. Leibson CL, Rocca WA, Hanson VA, Cha R, Kokmen E, O'Brien PC, Palumbo PJ: Risk of dementia among persons with 
diabetes mellitus: a population-based cohort study. Am J Epidemiol 1997, 145:301-308

20. Ott A, Stolk RP, van Harskamp F, Pols HA, Hofman A, Breteler MM: Diabetes mellitus and the risk of dementia: the Rotterdam Study. Neurology 1999, 53:1937-1942

21. Peila R, Rodriguez BL, Launer LJ; Honolulu-Asia Aging Study: Type 2 diabetes, APOE gene, and the risk for dementia and related pathologies: the Honolulu-Asia Aging Study. Diabetes 2002, 51: $1256-1262$

22. Janson J, Laedtke T, Parisi JE, O'Brien P, Petersen RC, Butler PC: Increased risk of type 2 diabetes in Alzheimer disease. Diabetes 2004, $53: 474-481$

23. Paulsson JF, Schultz SW, Kohler M, Leibiger I, Berggren PO, Westermark GT: Real-time monitoring of apoptosis by caspase-3-like protease induced FRET reduction triggered by amyloid aggregation. Exp Diabetes Res 2008, 2008:865850

24. Westermark GT, Gebre-Medhin S, Steiner DF, Westermark P: Islet amyloid development in a mouse strain lacking endogenous islet amyloid polypeptide (IAPP) but expressing human IAPP. Mol Med 2000, 6:998-1007

25. Betsholtz C, Christmansson L, Engstrom U, Rorsman F, Svensson V, Johnson KH, Westermark P: Sequence divergence in a specific region of islet amyloid polypeptide (IAPP) explains differences in islet amyloid formation between species. FEBS Lett 1989, 251:261-264

26. Mucchiano GI, Haggqvist B, Sletten K, Westermark P: Apolipoprotein A-1-derived amyloid in atherosclerotic plaques of the human aorta. J Pathol 2001, 193:270-275

27. Larsson A, Peng S, Persson H, Rosenbloom J, Abrams WR, Wassberg E, Thelin S, Sletten K, Gerwins P, Westermark P: Lactadherin binds to elastin-a starting point for medin amyloid formation? Amyloid 2006, 13:78-85

28. Ma Z, Westermark GT, Li ZC, Engstrom U, Westermark P: Altered immunoreactivity of islet amyloid polypeptide (IAPP) may reflect major modifications of the IAPP molecule in amyloidogenesis. Diabetologia 1997, 40:793-801

29. Soderberg O, Gullberg M, Jarvius M, Ridderstrale K, Leuchowius KJ, Jarvius J, Wester K, Hydbring P, Bahram F, Larsson LG, Landegren U: Direct observation of individual endogenous protein complexes in situ by proximity ligation. Nat Methods 2006, 3:995-1000

30. Baner J, Nilsson M, Mendel-Hartvig M, Landegren U: Signal amplification of padlock probes by rolling circle replication. Nucleic Acids Res 1998, 26:5073-5078

31. Puchtler H, Sweat F: Congo red as a stain for fluorescence microscopy of amyloid. J Histochem Cytochem 1965, 13:693-694

32. Wisniewski T, Golabek AA, Kida E, Wisniewski KE, Frangione B: Conformational mimicry in Alzheimer's disease. Role of apolipoproteins in amyloidogenesis. Am J Pathol 1995, 147:238-244

33. MacArthur DL, de Koning EJ, Verbeek JS, Morris JF, Clark A: Amyloid fibril formation is progressive and correlates with beta-cell secretion in transgenic mouse isolated islets. Diabetologia 1999, 42: $1219-1227$

34. Verchere CB, D'Alessio DA, Palmiter RD, Weir GC, Bonner-Weir S, Baskin DG, Kahn SE: Islet amyloid formation associated with hyperglycemia in transgenic mice with pancreatic beta cell expression of human islet amyloid polypeptide. Proc Natl Acad Sci U S A 1996, 93 : 3492-3496

35. Rajendran L, Honsho M, Zahn TR, Keller P, Geiger KD, Verkade P, Simons K: Alzheimer's disease beta-amyloid peptides are released in association with exosomes. Proc Natl Acad Sci U S A 2006, 103: 11172-11177

36. Dinkins MB, Dasgupta S, Wang G, Zhu G, Bieberich E: Exosome reduction in vivo is associated with lower amyloid plaque load in the 5XFAD mouse model of Alzheimer's disease. Neurobiol Aging 2014, 35:1792-1800
37. Jha S, Sellin D, Seidel R, Winter R: Amyloidogenic propensities and conformational properties of ProIAPP and IAPP in the presence of lipid bilayer membranes. J Mol Biol 2009, 389:907-920

38. Krampert M, Bernhagen J, Schmucker J, Horn A, Schmauder A, Brunner H, Voelter W, Kapurniotu A: Amyloidogenicity of recombinant human pro-islet amyloid polypeptide (ProIAPP). Chem Biol 2000, 7:855-871

39. Kajava AV, Aebi U, Steven AC: The parallel superpleated betastructure as a model for amyloid fibrils of human amylin. J Mol Biol 2005, 348:247-252

40. Eisenberg D, Jucker M: The amyloid state of proteins in human diseases. Cell 2012, 148:1188-1203

41. Figueroa DJ, Shi XP, Gardell SJ, Austin CP: Abetapp secretases are co-expressed with Abetapp in the pancreatic islets. J Alzheimers Dis 2001, 3:393-396

42. Baker HF, Ridley RM, Duchen LW, Crow TJ, Bruton CJ: Experimental induction of beta-amyloid plaques and cerebral angiopathy in primates. Ann N Y Acad Sci 1993, 695:228-231

43. Kane MD, Lipinski WJ, Callahan MJ, Bian F, Durham RA, Schwarz RD, Roher AE, Walker LC: Evidence for seeding of beta -amyloid by intracerebral infusion of Alzheimer brain extracts in beta -amyloid precursor protein-transgenic mice. J Neurosci 2000, 20:3606-3611

44. Walker LC, Callahan MJ, Bian F, Durham RA, Roher AE, Lipinski WJ: Exogenous induction of cerebral beta-amyloidosis in betaAPP-transgenic mice. Peptides 2002, 23:1241-1247

45. Eisele YS, Obermuller U, Heilbronner G, Baumann F, Kaeser SA, Wolburg H, Walker LC, Staufenbiel M, Heikenwalder M, Jucker M: Peripherally applied Abeta-containing inoculates induce cerebral beta-amyloidosis. Science 2010, 330:980-982

46. Ridley RM, Baker HF, Windle CP, Cummings RM: Very long term studies of the seeding of beta-amyloidosis in primates. J Neural Transm 2006, 113:1243-1251

47. Stohr J, Watts JC, Mensinger ZL, Oehler A, Grillo SK, DeArmond SJ, Prusiner SB, Giles K: Purified and synthetic Alzheimer's amyloid beta (Abeta) prions. Proc Natl Acad Sci U S A 2012, 109:11025-11030

48. Pype S, Moechars D, Dillen L, Mercken M: Characterization of amyloid beta peptides from brain extracts of transgenic mice overexpressing the London mutant of human amyloid precursor protein. J Neurochem 2003, 84:602-609

49. Eisele YS, Fritschi SK, Hamaguchi T, Obermuller U, Fuger P, Skodras A, Schafer C, Odenthal J, Heikenwalder M, Staufenbiel M, Jucker M: Multiple factors contribute to the peripheral induction of cerebral beta-amyloidosis. J Neurosci 2014, 34:10264-10273

50. Lamb BT, Call LM, Slunt HH, Bardel KA, Lawler AM, Eckman CB, Younkin SG, Holtz G, Wagner SL, Price DL, Sisodia SS, Gearhart JD: Altered metabolism of familial Alzheimer's disease-linked amyloid precursor protein variants in yeast artificial chromosome transgenic mice. Hum Mol Genet 1997, 6: $1535-1541$

51. Miklossy J, Qing H, Radenovic A, Kis A, Vileno B, Laszlo F, Miller L, Martins RN, Waeber G, Mooser V, Bosman F, Khalili K, Darbinian N, McGeer PL: Beta amyloid and hyperphosphorylated tau deposits in the pancreas in type 2 diabetes. Neurobiol Aging 2010, 31:1503-1515

52. Jackson K, Barisone GA, Diaz E, Jin LW, DeCarli C, Despa F: Amylin deposition in the brain: a second amyloid in Alzheimer disease? Ann Neurol 2013, 74:517-526

53. Hardy J, Selkoe DJ: The amyloid hypothesis of Alzheimer's disease: progress and problems on the road to therapeutics. Science 2002, 297: $353-356$

54. Ferrier GJ, Pierson AM, Jones PM, Bloom SR, Girgis SI, Legon S: Expression of the rat amylin (IAPP/DAP) gene. J Mol Endocrinol 1989, 3:R1-R4

55. Nicholl CG, Bhatavdekar JM, Mak J, Girgis SI, Legon S: Extrapancreatic expression of the rat islet amyloid polypeptide (amylin) gene. J Mol Endocrinol 1992, 9:157-163 
56. Fan L, Westermark G, Chan SJ, Steiner DF: Altered gene structure and tissue expression of islet amyloid polypeptide in the chicken. Mol Endocrinol 1994, 8:713-721

57. D'Este L, Wimalawansa SJ, Renda TG: Distribution of amylinimmunoreactive neurons in the monkey hypothalamus and their relationships with the histaminergic system. Arch Histol Cytol 2001, 64:295-303

58. Roggendorf W, Cervos-Navarro J: Ultrastructure of arterioles in the cat brain. Cell Tissue Res 1977, 178:495-515

59. Banks WA, Kastin AJ, Maness LM, Huang W, Jaspan JB: Permeability of the blood-brain barrier to amylin. Life Sci 1995, 57: 1993-2001
60. Chaitanya GV, Cromer WE, Wells SR, Jennings MH, Couraud PO, Romero IA, Weksler B, Erdreich-Epstein A, Mathis JM, Minagar A, Alexander JS: Gliovascular and cytokine interactions modulate brain endothelial barrier in vitro. J Neuroinflammation 2011, 8:162

61. Ganowiak K, Hultman P, Engstrom U, Gustavsson A, Westermark P: Fibrils from synthetic amyloid-related peptides enhance development of experimental AA-amyloidosis in mice. Biochem Biophys Res Commun 1994, 199:306-312

62. Westermark P, Lundmark K, Westermark GT: Fibrils from designed non-amyloid-related synthetic peptides induce AA-amyloidosis during inflammation in an animal model. PLoS One 2009, 4:e6041 